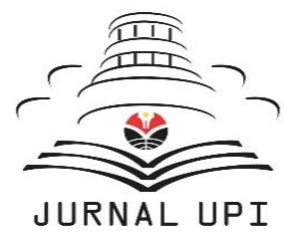

INDONESIAN JOURNAL OF APPLIED LINGUISTICS

Vol. 9 No. 2, September 2019, pp. 359-370

Available online at:

http://ejournal.upi.edu/index.php/IJAL/article/view/20233

doi: 10.17509/ijal.v9i2.20233

\title{
Issues on the initial impact of CEFR in Thailand and the region
}

\author{
Joseph Foley \\ The Graduate School of Human Sciences, Assumption University, Ramkhamhaeng Rd. Soi 24, Hua Mak, \\ Bangkok, 10240 Thailand
}

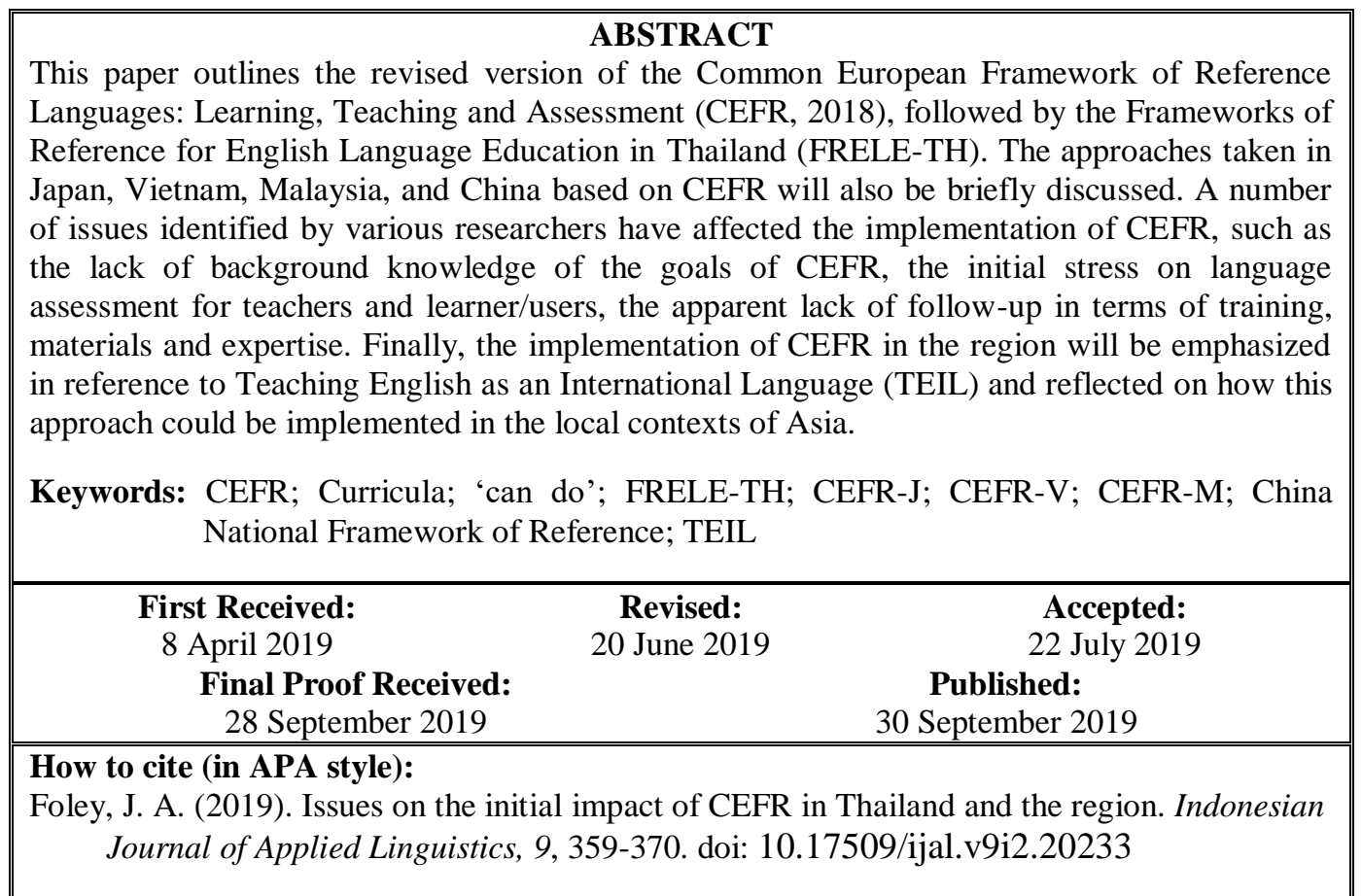

\section{THE COMMON EUROPEAN FRAMEWORK OF REFERENCE (CEFR)}

The Common European Framework of Reference (CEFR, 2001) was developed for adult foreign language learners to provide 'a common basis for the elaboration of language syllabuses, curriculum guidelines, examinations, textbooks, etc. across Europe' (Council of Europe, 2001, p. 1). At the core of CEFR was a set of six global levels, describing users as Basic (A1, A2), Independent $(B 1, B 2)$ and Proficient $(C 1, C 2)$. The levels describe competency in a wide range of communicative activities in the areas of spoken and written reception, interaction and production. There were also outlines in terms of scales of performance in areas including lexical, grammatical, sociolinguistic, discourse and pragmatic competence. Council of Europe (2018) in The Company Volume updated or modified several areas from the original version. It highlighted certain innovative areas for which no descriptor scales were originally provided, especially mediation and plurilingual/pluricultural competence. This was a major change for as well as modifying descriptors the removal of reference to 'native speaker' as the goal in the descriptors underlined the 'can do' element potentially available in speakers language repertoires. Further development of CEFR was in the defining 'plus levels' and a 'Pre-A1' level for learners and users as well as enriching the description at A1, and particularly C2.

One of the main purposes of CEFR is the promotion of the formulation of educational aims and outcomes at all levels. Its 'can do' aspects of proficiency are intended to provide a shared road-map for learning and a more nuanced instrument to gauge progress than a focus on scores in tests and examinations. The principle is based on the CEFR view of language as a vehicle for opportunity and success in social, educational and professional domains. This presents the language learner/user as a social agent, acting in the social world and exerting agency in the learning process (CEFR, 2018).

The CEFR action-oriented approach represents a move away from syllabuses based on linear progression 
through language structures, or a pre-determined set of notions and functions. The goal is a communication's perspective guided by what someone 'can do' in terms of the descriptors rather than a deficiency perspective focusing on what the learners have not yet acquired. Fundamentally, the CEFR, as originally devised, is a tool to assist the planning of curricula. Courses and examinations can be based on what the users/learners need to be able to do in the language in their own context. To further promote and facilitate cooperation, the CEFR provides common reference levels, A1-C2, defined by illustrative descriptors. CEFR is proposed more as a tool to facilitate educational reform projects, not a standardizing tool.

One of the major issues is whether the adaptations of CEFR in the region is leading to an over-emphasis on testing as a standardized tool of language proficiency. In the recent CEFR document, it was pointed out:

One thing should be made clear right away. We have NOT set out to tell practitioners what to do, or how to do it. We are raising questions and not answering them. It is not the function of the European Common Framework to lay down the objectives that users should pursue or the methods they should employ (CEFR: Notes to the User, 2018, p. 26).

The message from CEFR (2018) is that language learning should be directed towards enabling learners to act in real-life situations, expressing themselves and accomplishing tasks of different natures. The actionoriented approach puts the co-construction of meaning (through interaction) at the centre of the learning and teaching process. The construction of meaning may take place across languages and draw upon users/learners' plurilingual and pluricultural repertoires (translanguaging) and distinguishes between multilingualism, the co-existence of different languages at the social or individual level and plurilingualism, the developing linguistic repertoire of an individual user/learner (CEFR, 2018). The fundamental point is that plurilinguals have a single, inter-related, repertoire that they combine with their general competencies to accomplish tasks. Such tasks might require moving from one language to another or giving an explanation in another language to make sense of what is said or written (CEFR, 2018). The version of CEFR (2001) was originally established by the Council of Europe as part of the policies governing education, workplace entry, immigration and citizenship. At that time, any challenge to the construct of the CEFR (2001) would probably have had an effect on the implementation of CEFR (2001) and the tests linked to it, as many of the descriptors referenced native speakers as essential to the model. However, it was soon realized that not all native speakers could be equally good at communication, which involves flexibility and accommodation, the anticipation of communication difficulties and how to resolve them. Seidlhofer (2007) pointed out that the construct of English more as a lingua franca as a form of communication was, in fact, an important deficit in this earlier framework.
In the intervening years, the basic model has been maintained with two axes: a horizontal axis of categories for describing different activities and aspects of competence, and a vertical axis representing progress in proficiency in those categories. To facilitate the organization of courses and to describe progress, the CEFR (2018) presents the same six Common Reference Levels providing a roadmap that allows user/learners to engage with relevant aspects of the descriptive scheme in a progressive way with an important proviso that the six levels are not intended to be absolute (CEFR, 2018).

The authors of CEFR (2001) have never considered CEFR to be a completed or standalone document, indeed supporting work on CEFR scales was already underway in 2005 with the English Profile Programme (EPP) (Green, 2012).

Cambridge University has been developing reference level descriptions (RLD's) of English that provides language-specific guidance for each level of CEFR. Komorowska (2004) had found that teachers and teacher trainees did not like the CEFR's lack of guidance for choosing curriculum options, nor its nonevaluative approach to teaching methods. Costa (2007) expressed doubts about the empirical and statistical validation outside the original Swiss context, where it was being used. Hulstijin (2007) also indicated that the empirical foundations of the CEFR scales were based on the judgements of teachers and experts and not on Second Language (L2) processes or research. Also, Poszytek (2012) warned that publishers using CEFR's global scale or 'can do' concept to sell their textbooks were often misaligned with the CEFR scales and consequently, had limited theoretical background. Indeed, as CEFR has grown in popularity, there has been a tendency for some educational bodies and testing organizations to use CEFR categories without the required flexibility as all categories are conventional, socially constructed concepts.

Based on CEFR (2001), the English Profile Project and the British Council- EQUALS Core Inventory for General English have been developed to provide language support with more finally tuned contextually, discrete language points in both global and illustrative scales (North, Ortega, \& Sheehan, 2010). Equally important was the vertical and horizontal dimension of language development, as indicated in Figure 1. Reflecting the fact that users develop their overall communicative language competence by improving the quality of their language (vertical development) and expanding the breadth of communicative activities, they engage in (horizontal development). The idea of uneven proficiency profiles is referred to in CEFR as partial competence which is significant in that; it recognizes that a language user's proficiency is fundamentally uneven. No two users share the same language profile, as even the most proficient language user is unlikely to have the same proficiency across all of the CEFR's scales. Indeed, the CEFR's concept of partial competence can help in appreciating that language development does not solely 
have to be about moving up the vertical scale of complex language use. Broadening performance ability in communicative activities and strategies across domains is seen as equally important.

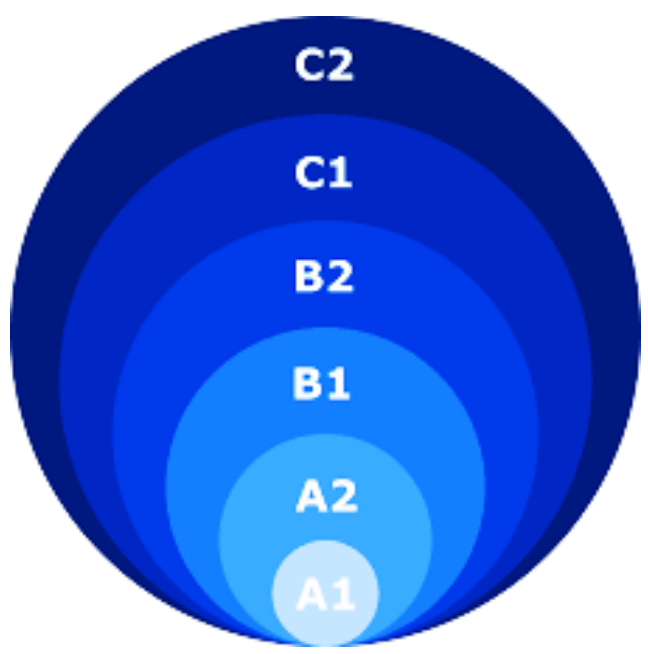

Figure 1. Vertical and horizontal axis

\section{ADAPTING THE FRAMEWORK OF REFERENCE FOR ENGLISH LANGUAGE EDUCATION IN THE REGION Thailand (FRELE-TH (2018)}

Using Thailand as an example of implementing CEFR, Thailand has been making the transition from a largely agrarian, low-income society to an upper-middleincome country but faces the challenge of achieving sustainable growth in the face of a shrinking workforce and regional competition. Thailand's basic education has expanded significantly and has been free since 2009. However, reform efforts to decentralize administration and increase the quality of education to meet broader development goals have up to now had less impact (UNDP Report, 2015). Thailand is ranked 53rd among 80 non-native speaking countries in the Education First Standard English Test (2017) with a score of 49.78, which is classified as low proficiency. According to the Thai Minister of Education, 40,000 Thai English teachers were tested using Cambridge English standards. Only six English teachers scored at C level, indicating fluency, 350 teachers scored at B level or intermediate, while the majority was at advanced beginners' level (Pollack, 2018). English, however, plays an increasingly important role in international communication for people in the region. This has seen an even greater emphasis on the ASEAN Economic Community Integration (AEC). With a view to enhancing the English abilities of Thai people to cope with and perform effectively in this changing context, in April, 2014, The English Language Institute (ELI), a branch of the Ministry of Education (MOE) announced a policy of basing all aspects of English language curriculum reform on the CEFR framework.

A local version of CEFR, the Frameworks of Reference for English Language Education in Thailand, (FRELE-TH (2017) was published including Evaluation and Accreditation of Quality Language Services (EAQUALS). The FRELE-TH has two scale types to describe the English proficiency levels: a global scale (overall descriptors) and illustrative scales, (communicative activities, communication strategies, and communicative language competence). FRELE-TH was developed by Chulalongkorn University Language Institute and the Language Institute of Thammasat University with several other organizations and 'stakeholders.' FRELE-TH also adopted components from EAQUALS (North, 2008), the Threshold Level (Trim \& Trim, 1980; van Ek \& Trim, 1990), the Core Inventory of General English (North et al., 2010), the English Profile Program (Salamoura \& Saville, 2010) and the Word Family Framework (West, 2015). The FRELE$\mathrm{TH}$ used the plus (+) levels from the Swiss Project (Goullier, 2007) to make sure that Levels, A (Basic User) and B (Independent User) were not too high for Thai learners to achieve these levels of performance (Hiranburana et al., 2018). Outlining more discrete levels makes sense for pedagogical reasons (North, 2004, p.48) as it shows that the FRELE-TH framework following CEFR is flexible, allowing levels and categories to merge and sub-divide as appropriate. A similar practice can be seen in the CEFR-J for use in Japan (Negishi, Takada, \& Tono, 2013) and in China by three stages divided into nine levels (National Education Examinations Authority [NEEA], 2018).

The context of introducing CEFR in the region can be very different as the example of Thailand illustrates: the poor levels of English, poorly-trained teachers, poorly-motivated students and rare opportunities for students to have exposure to English outside the classroom (Dhanasobhon, 2006). The rationale behind the development of FRELE-TH lies in the principle of CEFR's inception that CEFR does not offer ready-made solutions but must be adapted to the requirements of particular contexts. In order to meet these objectives, a 10-level reference framework was developed as an adaptation of CEFR to make it relevant to English use in local and international communication in Thailand. English is one of the working languages in the ASEAN Economic Community (AEC), not only in education but for job applications and work promotion (Pitsuwan, 2014). However, many Thai people do not have satisfactory proficiency in English. This is despite the 912 years that Thai students spend in learning English in formal education. Consequently, the English language reform policy in Thailand (Ministry of Education, 2014) announced the use of CEFR in the design of language curricula, learning goals, testing and assessment as well as the development of the teaching (Hiranburana et al., 2018). To do this, FRELE-TH, descriptors were reviewed and improved to make them more comprehensible and relevant to Thai learners and users of English. For example, the A1 level has taken into consideration the fact that users of English begin with words, phrases, and simple expressions with 'Can Do' statements on familiar topics and immediate surroundings (see Figure 2). It was also hoped that the 
FRELE-TH global scale could be used for the design of specifications on the high-stakes standardized tests of English proficiency, the results of which can be benchmarked with those of international standards. In this way, in principle, students and users' performance and progress can be measured and tracked to be calibrated with other international standards for educational and professional purposes (Hiranburana et al., 2018).
The FRELE-TH based initially on (CEFR, 2001), maintained the structure and three components of the CEFR communicative activities, communication strategies, and communicative linguistic competence with their sub-components, as shown in Table 1.

As can be seen in Table 2, FRELE-TH standard levels equivalence to the CEFR and the CEFR with the plus levels.

\title{
A1 learners Descriptors
}

Can recognize simply vocabulary and basic expressions concerning themselves or their family. Can understand and reply to simply expressions spoken very clearly and slowly

\author{
A2 learners \\ Can use basic sentence patterns and groups of phrases to communicate and describe personal information, routine \\ activities and requests
} \begin{tabular}{l}
\hline B1 learners \\
\hline $\begin{array}{l}\text { Can understand the main points of clear speech on familiar topics. Can work out the main points they want to } \\
\text { communicate in a range of contexts. }\end{array}$ \\
\hline
\end{tabular}

\section{B2 learners}

Can understand the main ideas of complex speech on concrete and abstract topics, including technical discussions in their field of specialization.

\section{C1 learners}

Have a good command of vocabulary including some idiomatic expressions and speaks fluently

\section{C2 learners}

Have no difficulty in understanding any kind of spoken language, whether live or broadcast. Can express thoughts fluently and effectively. Can use a variety of cohesive devices in written language to produce a coherent and cohesive text.

Figure 2. Examples of 'Can Do’ descriptors.

Table 1. Structure and components of FRELE-TH

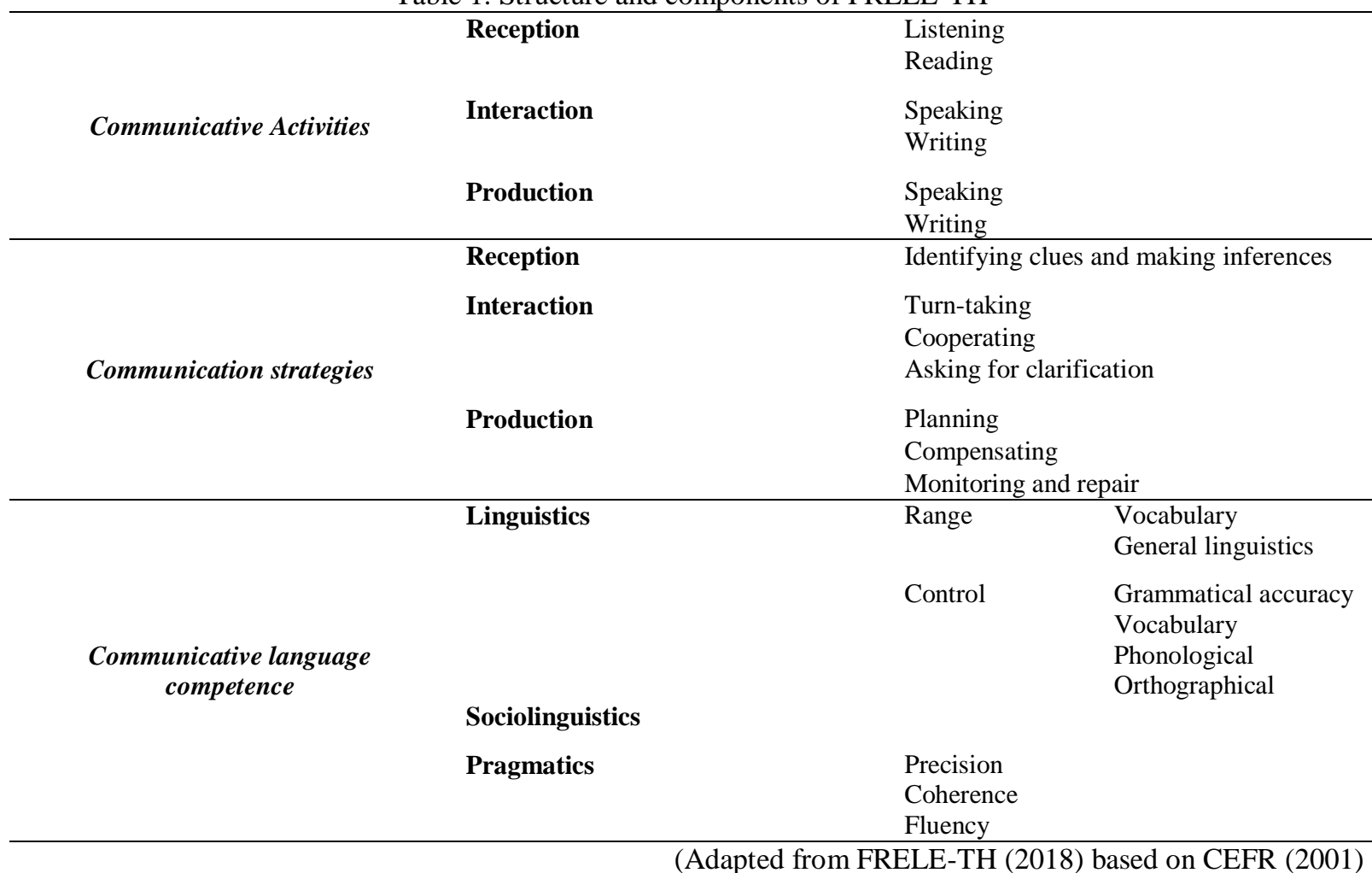


Table 2. FRELE-TH Equivalency

\begin{tabular}{|c|c|c|}
\hline FRELE-TH & $\begin{array}{c}\text { CEFR } \\
\text { Proficiency level }\end{array}$ & FRELE-TH level \\
\hline $\begin{array}{l}\mathrm{A} 1 \\
\mathrm{~A} 1+\end{array}$ & A1 & Basic User \\
\hline $\begin{array}{l}\mathrm{A} 2 \\
\mathrm{~A} 2+\end{array}$ & A2 & $\begin{array}{l}3 \\
4\end{array}$ \\
\hline $\begin{array}{l}\mathrm{B} 1 \\
\mathrm{~B} 1+\end{array}$ & B1 & Independent \\
\hline $\begin{array}{l}\mathrm{B} 2 \\
\mathrm{~B} 2+\end{array}$ & B2 & $\begin{array}{l}7 \\
8 \\
\end{array}$ \\
\hline $\mathrm{C} 1$ & $\mathrm{C} 1$ & Proficient \\
\hline $\mathrm{C} 2$ & $\mathrm{C} 2$ & 10 \\
\hline
\end{tabular}

(Adapted from FRELE-TH (2018) based on CEFR (2001))

As shown in Table 3, FRELE-TH also has been used to assess the English abilities of Thai learners and users of English in academic settings and professional contexts to suggest the following standards. After three years of up to 5 hours contact, the academic ability of all the groups would be expected to reach the higher end of the range at the current level of English.

This adapted table of selected professions, in Table 4, indicates that Thai users of English need to have a wide range of English abilities depending on their profession, from taxi driver at level $2(\mathrm{~A} / \mathrm{A}+)$ to those professions requiring a high degree of negotiation skills at level $10(\mathrm{C} 2)$. The establishment of the ASEAN Economic Community (AEC) in 2015 with its internal labour market and English as its sole working language raised concerns about Thailand's economic competitiveness. The adoption of CEFR and the contracting of the British Council to deliver a CLTbased training program for Thai English language teachers were presented as a potential solution to Thailand's English language problems (Mala, 2016). In fact, Thailand was rather late in joining the trend of countries embracing CEFR to reform their English language curriculums and assessment mechanisms. However, more recently, a consortium of 12 Thai universities has been formed to stimulate and propagate the use of FRELE-TH in the education system.

Table 3. Expected English ability

\begin{tabular}{lcll}
\hline \multicolumn{1}{c}{ Academic level } & Current ability level & \multicolumn{2}{c}{ Expected after 3 years } \\
\hline Prathom 1-3 & $1-2$ & 2 & $\mathrm{~A} 1+$ \\
Prathom 4-6 & $2-3$ & 3 & $\mathrm{~A} 1+/ \mathrm{A} 2$ \\
Lower Secondary & $2-4$ & 4 & $\mathrm{~A} 2$ / A2+ \\
Upper Secondary & $4-5$ & 5 & $\mathrm{~A} 2+/ \mathrm{B} 1$ \\
Vocational & $2-4$ & 4 & $\mathrm{~A} 1+/ \mathrm{A} 2+$ \\
Tertiary & $4-6$ & $4-6$ & $\mathrm{~A} 2+/ \mathrm{B} 1$ \\
\hline
\end{tabular}

(adapted from Hiranburana et al., 2017)

Table 4. Examples of the suggested standard of levels in the professions

\begin{tabular}{lcccc}
\hline Professional & Listening & Reading & Speaking & Writing \\
\hline Tourist Guide & 10 & $7 / 9$ & 10 & $5 / 8$ \\
Teacher of English & $8 / 10$ & $8 / 9$ & 9 & 9 \\
Nurse & $5 / 6$ & $6 / 7$ & 5 & 5 \\
Taxi Driver & 3 & 2 & 3 & 2 \\
Hotel Front Manager & $9 / 10$ & $9 / 10$ & $9 / 10$ & $9 / 10$ \\
Tourist Police & $3 / 7$ & $3 / 6$ & $3 / 6$ & $3 / 7$ \\
Flight attendant & $4 / 8$ & $4 / 5$ & $4 / 5$ & $4 / 5$ \\
\hline
\end{tabular}

(adapted from Hiranburana et al., 2017)

Japan in 2012 developed CEFR-J to suit the Japanese EFL context by re-mapping the 'can do' statements and subdividing the lower proficiency levels and $\mathrm{B}$ by adding sub-levels to allow for more differentiation at the levels relevant to the majority of Japanese learners (Tono \& Negishi 2012).

In 2008, Vietnam ratified 'Project 2020' to improve English language proficiency by basing the reform efforts around a CEFR framework to facilitate the teaching of English under Vietnamese conditions (Chung, 2014).
In Malaysia, the alignment of the education system against CEFR was seen as an important step in the Malaysia Education Blueprint with the aim to boost the level of education to international standards (Azman, 2016).

In China, the development of a national framework of reference was one of the responses to this need for a more transparent education system (Jin, Wu, Alderson, \& Song, 2017). China's Standards of English Language Ability (CSE) (2018) has been developed by the National Education Examinations Authority (NEEA) as the national framework of reference for English 
language education as has happened in several other countries in the region.

\section{Japan: CEFR-J}

Japan used a modified version, CEFR-J to ensure that the framework reflected its local standards in teaching and learning, curriculum development, as well as assessment (Bucar, Ryu, Skof, \& Sangawa, 2014). Part of the impetus for change came from the need to transition from a knowledge-based English curriculum to a competency-based language one. Stakeholders' consent for a new skill-based language curriculum was more in favour of curriculum objectives that aimed at marketable results on reputable language proficiency tests (Moser, 2015). However, it was also realized that the proficiency level in English of students enrolling in tertiary education was too low to achieve the proficiency test results required. It was suggested that CEFR's globally recognized 'can do' scales could be used as these scales identified language gains at the lowest levels of language proficiency. The CEFR-J through the Japanese Ministry of Education, Culture, Sports Science and Technology (MEXT, 2011) published a report encouraging the use of 'can do' lists in junior and senior high schools.

The 'can do' lists which were established, in addition to using the CEFR descriptors, used triangulation with banks of descriptors for EQUALS/ALTE, ELP as well as textbooks influenced by CEFR such as Longman's Total, and Cambridge University Press' English Unlimited (Naganuma,2010). Negishi et al. (2013) survey of Japanese EFL users indicated that 80 per cent were between A1 and A2. CEFR-J, unlike CEFR, introduced scales using a branching approach with narrower levels of $\mathrm{A} 1+$ and A2+; B1+ and B2+. Negishi et al. (2013) the authors of CEFR-J stated, this was an attempt to make CEFR more useable in the Japanese context. It was felt that this increase in sub-levels allowed teachers to fine-tune student assessment, which meant being able to create more separation between students within a band. This use of CEFR-J scales allowed students of near A2 or A2 students who did not see their progress improve on the vertical scales of the program because of the longer time needed to acquire skills to be considered as A2+ or B1 (Moser, 2015).

As North (2007) pointed out a branching approach with its narrow levels would allow teachers and students to see more progress, which especially at the earlier levels is critical for developing motivation. A drawback of this narrower scaling was that distinguishing these sub-levels became more nuanced and created a little more variability in teacher assessment.

\section{Vietnam: CEFR-V}

The Vietnamese Ministry of Education and Training (MOET) in 2008 decided to officially use CEFR to define English language exit benchmarks for students ranging from primary through to tertiary levels of education. The national project Teaching and Learning
Foreign Languages in the National Education System 2008-2020 (Hung, 2013) expected all university graduates not majoring in languages to reach B1 English. MOET also adopted CEFR levels A1 (beginners) $\mathrm{A} 2$ and $\mathrm{B} 1$ as the required standards for students leaving Primary, Junior and Secondary High schools (Nguyen, 2015). Nguyen Loc, the Vice director of MOET's National Institute for Educational Strategies and Curriculum, stated that the strategic cooperation with Cambridge English Language Assessment was playing a key role in the innovation process of English teaching learning and assessment in Vietnam. However, in a meeting organized by the education ministry, university and government representatives it was reported that the government's targets for language proficiency were too ambitious (Nguyen \& Hamid, 2015; Nguyen, Wilkinshaw \& Pham, 2017). According to a survey quoted by Nguyen Thi Lan Anh, a university department head, only one in five students could achieve that level in 2015. The consequence, according to the deputy director of Thai Nguyen University was that, the institution had to lower the requirement to A2. The reasons given for not reaching the targets were the teachers' poor English, lack of resources and outdated teaching methods with a heavy focus on traditional grammar. The government has reportedly moved some of the objectives of the language learning and teaching plan to 2025. Nguyen Duc Hoat, former Dean of the English Faculty of the Hanoi Foreign Trade University suggested that a new approach should be undertaken, creating CEFR-V, a Vietnamese version, similar to CEFR-J. Vu Thi Tu Anh, deputy head of the Management Board for the National Foreign Language Teaching Program, indicated that the original framework would be adjusted to make it more suitable for Vietnamese studying foreign languages. However, Anh also warned that as it will take a long time to fulfil the English teaching program, with MOET now focusing on training teachers of English. It is expected that Vietnam would need 100,000 teachers to fulfil the program's objectives (Viet, 2015)

\section{CEFR-M and Malaysia Education Blueprint}

The implementation of CEFR in Malaysia started with the establishment of English Language Standards and Quality Council (ELSQC) 2013. Alignment of the education system with CEFR was an important element in the Malaysia Education Blueprint (MEB) with the aim to boost the level of education to international standards (Azman, 2016). The implementation of CEFR in MEB (2018) brought about an additional impact on English language education especially in primary schools as CEFR was to be included with the already existing Literacy and Numeracy Screening or LINUS program. Students' proficiency was to be graded using CEFR descriptors in order to ensure that students' grades were recognized at international levels. LINUS 2.0 also incorporated English language literary skills so that integration of language proficiency assessment was to be shared between LINUS 2.0 and CEFR. However, 
only the first three levels of CEFR descriptors (A1, A2, and B1) were to be used in this integration because of the low proficiency of the students and the fact that they might progress at a slow pace.

Although, CEFR is in part a language policy intended to define levels of language proficiency in terms of real-world practical ability it was felt that the integration of LINUS and CEFR was necessary to take into account the reality of the Malaysian education landscape (Ishak \& Mohamad, 2018). More recently, it was reported (Menon, 2019) that the Education Ministry was to introduce later in the year a Form 3 (PT3) new English exam aligned to the CEFR as this was an international benchmark for English proficiency. As part of the effort to improve English in Malaysia, the Education Director-General also issued a circular stating that English option teachers should have a minimum of CEFR, C1 level of qualification as 20,534 teachers had not yet taken any test to determine their level of English proficiency. The MEB (MoE, 2013) is a long-term goal with the main aim to provide successful language education starting from pre-school up to tertiary education.

The roadmap consists of three phases:

Phase 1 (2013-2015) focused on raising the level of English proficiency of teachers.

Phase 2 (2016), in the first part, appropriate CEFR levels were to be matched against educational levels starting from preschool to teacher education. The second part of Phase 2, School Based Assessment (SBA), syllabus and curricula were also aligned with CEFR descriptors (National Education Blueprint, 2013).

Phase 3 is for ELSQC to evaluate, review and revise the implementation of CEFR.

The focal point for phase 3 is the development of CEFR-M based on the revision needed to implement the changes. However, some of the issues that have arisen in spite of the teachers generally accepting the framework of CEFR are the limited background knowledge, minimum exposure and low level of awareness about CEFR. This must be added to teachers' own English proficiency, their natural resistance to change and lacking CEFR experts who are able to construct and produce local CEFR aligned textbooks. This must be because of the lack of training and the notion that most teachers feel it would be difficult to incorporate CEFR in their teaching (Mohamad Uri, \& Sallehhudin Abd Aziz, 2017; Lo, 2018).

\section{China Standard of English (CSE) and the national framework of reference}

Apart from the internal needs and interests of the Chinese government to improve English language education, there is an ever-increasing external influence to respond to the challenge of globalization by making the education system more transparent to the outside world. The development of a national framework of reference is one of the responses to this need for a more transparent education system (Jin et al., 2017). China's Standards of English Language Ability (CSE) (2018) has been developed by the NEEA as the national framework of reference for English language education. The management structure of education in China has had different governmental departments taking charge of education at different stages.

One of the issues arising from such management structure was the inconsistent learning objectives specified in the curricula for learners of English at each educational stage.

Another issue was reflected in the proficiency levels of national assessment aligned to the curriculum at each educational stage. Depending on their purpose, these assessments fell into three main categories: admission test, program exit test and proficiency test, together with the fact that these tests were developed and administered by different testing organizations.

The recent introduction of a common English proficiency scale is hoped it will facilitate test construction and score interpretation. China has developed a nine-level scale based on CEFR (2001) so that the standards of English language education can be aligned to international frameworks, thus prepares Chinese people to become global citizens. It is also significant that the descriptive framework for knowledge has sub-divisions of organizational knowledge (grammatical and textual); pragmatic knowledge (functional and sociolinguistic) and interpreting and translation following the genres outlined in sociolinguistic knowledge.

In general, this seems to reflect a much more 'functional' approach to language knowledge than in the original CEFR (2001) document. For example, sociolinguistic knowledge is subdivided into genres, dialects/varieties, registers, and idiomatic expressions and cultural and figures of speech. As mediating activities, interpretation and translation occupy an important place in the linguistic function of Chinese society and are taught as a language skill at a tertiary level of education. Issues have also been identified particularly with the use of CEFR for developing examinations. Papageorgiou (2010), identified problems with some of the descriptors when used for setting cutoff scores, as CEFR was not designed specifically for test specifications. More importantly, in the Chinese context, the CEFR (2001) 'can do' descriptors were too narrowly focused to be useful for teachers to reflect on teaching and to construct a teaching syllabus. A key difference between CEFR (2001) and CSE is in the target users. CSE is intended for Chinese learners of English at all educational stages, whereas, as previously indicated, CEFR was developed to aid foreign language learning in an adult context in Europe.

\section{Indonesia's English language proficiency}

CEFR has not yet gained currency in English language teaching outside of universities (Renandya, Hamied, \& Nurkamto, 2018). According to this study, nationwide 
official data on teachers' language proficiency, in general, is not available. Coleman (2009) reported that 27,000 teachers took the TOEIC test, but only half of all teachers and headteachers had a 'novice' proficiency level in English, scoring between 10 and 250 on a 990point scale.

Fresh graduates from teacher education colleges seem to show varied levels of proficiency using TOEFL scores of 450 to 525 , although some elite universities require a higher TOEFL score (Renandya et al., 2018). Of course, there is the question of whether TOEIC and TOEFL can accurately reflect English proficiency, and how we can compare such scores to the levels indicated in CEFR. To add to this is the fact that language teaching contexts in Indonesia are more complex than possibly other countries in the region. There is also the issue of the national exams which have become well established and in general accepted by stakeholders as indicating benchmarks in language proficiency. The issue for educators and administrators in the Indonesian context concerns the benefit of replacing the present system with an Indonesian version of CEFR for English although one exists for French, at least at university level.

\section{REVIEWING THE ISSUES}

Competency in a language is a multi-dimensional system that accounts for the situations, the functions, the linguistic elements needed in communicative competencies. However, measures of language competency can be arbitrary. North (2000) pointed out that CEFR as originally designed was a common measure for recording language competence and that the motivation for a common framework was more pragmatic (thus the 'can do') rather than academic. However, there were some inherent limitations in the original version of CEFR (2001) which did affect its applicability, not only in Europe but also in other parts of the world (Fulcher, 2004). There was in the CEFR (2001) a lack of empirical evidence between the products and the research to underpin the descriptions and reference levels of CEFR (2001) in its early stages. Consequently, as already mentioned, examination providers, textbook publishers and curriculum developers made claims about the relationship between their products and CEFR (2001) but little hard evidence was produced to back up such claims (Alderson, 2007).

Creating a language competency framework for Thailand, Japan, Malaysia, Vietnam, and China has involved decisions which are more than simply transferring CEFR to other educational contexts. The various implementations of CEFR in this part of the world have been based on CEFR (2001) as the revised version of (2018) came later. In spite of the fact that in general teachers and government officials' views saw the potential for the implementation of CEFR to help to raise the level of competence in English within the contexts of their educational system. The way CEFR was introduced has led many teachers to associate
CEFR with the framework's proficiency scale with possibly too much emphasis on testing, supporting what Freeman (2017) called a 'deficit view' of teachers and their teaching abilities. Wider forms of self-assessment advocated by the developers of CEFR seem to have been missed. In Thailand, the feedback on the 2015 online CEFR-based placement test using either Cambridge/ Oxford exam board was considered by the teachers as being more suitable for a European context. The teachers did not object to being tested as they wanted to improve their English proficiency as they felt it needed to be higher than their students. But for those English teachers below B1 in the test, there was little additional support from the Ministry of Education in terms of offering special assistance (as it was to those attaining B 1 and above) to help improve their English proficiency (Franz \& Teo, 2018). A comparison between the Thai CEFR policy, the Vietnamese Project 2020 and the Malaysian road-map shows a number of similarities: ambitious target levels for students and teachers, centralized decision making and the need to resort to external consultancies. In general, teachers had very limited knowledge and exposure to CEFR.

There were issues with the teachers' level of English proficiency:

1) the traditional resistance to change

2) the lack of local CEFR experts who were able to construct and produce local CEFR textbooks

3) the lack of adequate training and the notion that many teachers had that it would be difficult to incorporate CEFR in their teaching

In China, a major difference between CEFR (2001) and CSE lay in the enormous range of target users. CSE is intended for Chinese learners of English at all educational stages just as FRELE-TH in the Thai context. It has already been pointed out that CEFR (2001) was developed for foreign language learning in the adult context in Europe. Also, a six-level structure in China, as with Thailand, did not seem to suit the needs of China in providing guidance to English language teaching and learning. Although the CEFR has an open and flexible structure which allows a breakdown into sub-levels, China needed a framework tailored to the needs of English language teaching in China in addition to listening, speaking, reading and writing, interpretation and translation have to be added to fit the language curriculum. What this has required is extensive research into the motivations, domains and levels of language proficiency that will be more attuned to Chinese learners. Indeed, as Byrnes (2007) pointed out the dangers of the simple and inappropriate transfer of CEFR content to other educational contexts called for CEFR - research to focus more on 'how a context-free, though by no means context-indifferent, framework like CEFR can and should be translated into contextrelevant forms in diverse educational environments in order to be implemented' (p.642-643). 
Finally, the issue, as initially raised by Seidlhofer (2007) concerned the construct of English as a lingua franca as a form of communication which was originally absent from the CEFR (2001). In the last twenty or more years, there has been a tendency for the such 'can do' approaches to be more in tuned with Teaching English as an International Language (TEIL) (Marlina, 2018). However, the issue is how to reconcile TEIL as presently conceptualized with the CEFR in local contexts. Those responsible for language education in the region perceive the goal-oriented 'can do' descriptors and illustrators as being adapted for local versions of CEFR as well as being designed towards some degree of uniformity in goals to be achieved in a transparent assessment system across the region. The argument for the use of English as an International Language (EIL) has been more than simply a variety of English developed and used for communicative purposes in international contexts. EIL recognizes the values of all varieties of English at national, regional and social level (Marlina, 2018). Matsuda (2018) sees EIL as a pedagogical approach grounded in the contemporary sociolinguistic reality of English that equips learners with the necessary knowledge, attitudes, skills and strategies for living in the 'messy'....and 'unpredictable' world of English today (p. 25). Both these statements and several others could equally accord with the goals of CEFR (2018) version.

CEFR's original intention has been that language learning should be directed towards enabling learners to act in real-life situations, expressing themselves and accomplishing tasks of different natures. It would seem that the whole point of the development of local varieties of CEFR is '...to define 'can do' statements of users and learners of English relevant to the context of local and regional and international communication (Preface: FRELE-TH, iii 2017).

The action-oriented approach puts the coconstruction of meaning (through interaction) at the centre of the learning and teaching process. Such construction of meaning, normally, take place across languages and draw upon users/learners' plurilingual and pluricultural repertoires (translanguaging). McKay (2018) has argued that EIL is informed in terms of its basic principles that support a pluricentric view of standards, recognizing the value of students' other languages and promotes pragmatic sensitivity towards the other cultures involved. Given the linguistic and cultural complexity of English, it is advocated that all pedagogical decisions be based on the local linguistic and cultural contexts. With EIL having apparently similar aims to CEFR, the issue really depends on whether TEIL will be acceptable to teachers, administrator, educational authorities and even students particularly in relation to high-stake international forms of assessment. International recognition of the levels attained using CEFR is a major goal for educational authorities in the region given the reality of the lowlevel of English.

\section{THE DILEMMA: STRIKING A BALANCE}

The emergence of the Asian-Pacific economies, the rethinking of pluralism and multilingualism are in flux with linguistic dynamism. A century ago, Ferdinand de Saussure (1914/74) wrote about the contrasting principles of provincialism (ésprit de clocher) and intercourse. On the one hand, he argued, provincialism keeps a community faithful to its traditions and encourages cultural continuity. On the other hand, there is an opposing force, the need for broader communication for which Saussure used the English word intercourse. What this reflects is a tension in desires to retain something local, traditional or 'authentic'. We have to recognize that English in a global context will be subject to variation and change as it spreads into different domains of use and communities of users. Languages do not vary and change proactively under their own steam but reactively in response to certain social forces. We are talking about matters of pluralism and assimilation which CEFR has been attempting to address, as well as, linguistic practicality, communicative efficiency, social mobility and economic advancement. This means balancing the need for an awareness of other varieties of English with the need for transparency in what is nationally and internationally acceptable in terms of being a competent language user.

\section{REFERENCES}

Alderson, J. (2007). The CEFR and the need for more research. The Modern Language Journal, 91(4) 695-663. doi: 10.1111/modl.2007.91.issue-4

Azman, H. (2016). Implementations and challenges of English Language education reform in Malaysian Primary Schools. 3L: The Southeast Asian Journal of English Language Studies, 22(3), 65-78. doi: 10.17576/3L-2016-2203-05

Bučar, S. C., Ryu, H., Moritoki Škof, N., \& Hmeljak Sangawa, K. (2014). The CEFR and teaching Japanese as a foreign language. Linguistica, 54(1), 455-469. https://doi.org/10.4312/linguistica.54.1.455-469.

Byrnes, H. (2007). Perspectives. The Modern Language Journal, 91(4), 641-645.

Chung, V. (2014, November 15). Vietnam considers using CEFR-V standard for English teaching. Vietnamnet Bridge. Retrieved from http://english.vietnamnet.vn/fms/education/116476 /vietnam-considers-using-cefr-v-standard-forenglish-teaching.html

Coleman, H. (2009). Indonesia's 'International Standard Schools': What are they for? $8^{\text {th }}$ Language and Development Conference. Dhaka, 23-25 June 2009.

Costa, D. (2007). Contextualizing uses of the common European framework of reference for languages, In Council of Europe, The common European framework of references for languages (CEFR) and the development of language policies: 
challenge and responsibilities. Strasbourg: Council of Europe. (40-49). [Online URL]

www.coe.int/t/dg4/linguistics/Publications_en.asp

Council of Europe (2001). Common European framework of reference for languages: Learning, teaching and assessment. Strasbourg: Council of Europe, Language Policy Unit.

Council of Europe (2018). Common European framework of reference for languages: Learning, teaching and assessment. Strasbourg: Council of Europe, Language Policy Unit.

Dhanasobhon, S. (2006). English language teaching dilemma in Thailand. Asociation Curriculum and Instruction Thailand (ACIT). Retrieved from http://www.curriculumandinstruction.org/index.ph $\mathrm{p}$ ?lay $=$ show $\&$ ac $=$ article $\& I d=539134523 \&$ Ntype $=7$

Education First Standard English (2017). Test Proficiency Index. [Online URL] https://www.ef.co.th/epi/

Franz. J, \& Teo, A. (2018). 'A2 is normal'- Thai secondary school English teachers' encounters with CEFR. RELC Journal, 49(3), 322-338. doi: $10.1177 / 0033688217738816$

Freeman, D. (2017). The case for teachers' classroom English proficiency. RELC Journal, 48(1), 31-52. doi: $10.1177 / 0033688217691073$

Fulcher, G. (2004). Deluded by artifices? The common European framework and harmonization.

Language Assessment Quarterly, 1(4), 253-266. doi: 10.1207/s15434311laq0104_4

Goullier, F. (2007). Impact of the Common framework of Reference for Languages and the Council of Europe's work on the New European educational area, in Council of Europe (2007) The common European framework of references (CEFR) and the development of language policies: Challenges and responsibilities, Strasbourg: Council of Europe.

Green, A. (2012). Language functions revisited: Theoretical and empirical bases for language construct definition across the ability range. English Profile Studies (vol. 2), Cambridge: Cambridge University Press.

Hiranburana, H., Subphadoongchone, P., Tangkiengsirisin, S., Phoochaeoensil, S., Gainey, J., Thogsongsri , J., ... \& Taylor, P. (2017). A framework of reference for English Language education in Thailand (FRELE-TH) - based on the CEFR, The Thai experience. LEARN Journal, 10(2), 90-119.

Hiranburana, H., Subphadoongchone, P., Tangkiengsirisin, S., Phoochaeoensil, S., Gainey, J., Thogsongsri , J., ... \& Taylor, P. (2018). Framework of Reference for English Language Education in Thailand - (FRELE-TH). Based on CEFR: Revisited in the English Educational Reform. Pasaa Paritat Journal, 33, 51 - 91.

Hulstijn, J. (2007). The shaky ground beneath the CEFR quantitative and qualitative dimensions of language proficiency. The Modern Language
Journal, 91(4) 663-667. doi: 10.1111/j.15404781.2007.00627_5.x

Hung, N.N. (2013).Vietnam's National Foreign Language20/20 Project. [Online URL] http://www.amchamvietnam.com/wpcontent/uploads/2013/07/130319-20-NNHNational-Foreign-Languages-2020-ProjectPresentation-at-Vietnam-Engineering-EducationConference-web.pdf

Ishak,W \& Mohamad, M. (2018). The implementation of common European framework of reference (CEFR): What are the effects towards LINUS students' achievements? Creative Education, 9 2714-2731. doi: 10.4236/ce.2018.916205

Jin, Y. Wu, Z., Alderson, C., \& Song, W. (2017). Developing the China standards of English:Challenges at macropolitical and micropolitical levels. Language Testing in China, 7(1), 1-19. doi: 10.1186/s40468-017-0032-5

Komorowska, H. (2014). The CEF in pre- and inservice teacher education. In K. Morrow (Ed), Insights from the common European framework (pp. 55-64). Oxford: Oxford University Press.

Lo, Y.Y. (2018). English teachers' concern on common European framework of references for languages (CEFR): An application of BAM. Juku: Jurnal Kurikulum, dan Pengajaran Asia Pasifik 6(1). 4658.

Mala, D. (2016, March 9). English in the news: govt launches app, teacher's 'boot camp.' Bangkok Post. Rtrieved from https://www.bangkokpost.com/learning/learningnews/891472/english-in-the-news-govt-launchesapp-teachers-boot-camp

Marlina, R. (2018). Revisiting the pedagogy of English as an international language. RELC Journal, 49(1), 3-8. doi: 10.1177/0033688218765831

Matsuda, A. (2018). Is teaching English as an international language all about being politically correct? RELC Journal, 49(1), 24-35. doi: $10.1177 / 0033688217753489$

McKay, S.L. (2018). English as an international language: What it is and what it means for pedagogy. RELC Journal, 49(1), 24-35. doi: 10.1177/0033688217753489

Menon, S. (2019, May 4). English proficiency move needs time. The Star newspaper. Retrieved from https://www.thestar.com.my/news/nation/2019/05/ 04/english-proficiency-move-needs-time/

Commission on the Development of Foreign Language Proficiency [MEXT]. (2011). Five proposals and specific measures for developing proficiency in English for international communication.Ministry of Education, Culture, Sports, Science and Technology of Japan [MEXT]. Available online at http://www.mext.go.jp/component/english/_icsFil es/afieldfile/2012/07/09/1319707_1.pdf

Ministry of Education Malaysia (2013). Malaysia Education Blueprint 2013-2025. Putrajaya: Ministry of Education Malaysia: [Online URL] 
https://www.ilo.org/dyn/youthpol/en/equest.fileutil s.dochandle?p_uploaded_file_id=406

Mohamad Uri, N.F. \& Sallehhudin Abd Aziz, M. (2017). CEFR in Malaysia: Current issues and challenges in the implementation of the framework. The $3^{\text {rd }}$ International Conference on Language Testing and Assessment and $5^{\text {th }}$ British Council New Directions in Language Assessment Conference 2-3 December 2017. Shanghai, China.

Moser, J. (2015). From a knowledge-based language curriculum to a competency-based one: The CEFR in action in Asia. Asian EFL Journal, 88, 113-135.

Naganuma, N. (2010). The range and triangulation of can do statements in Japan. In M.G. Schmidt, N. Naganuma, F. O’Dwyer, A. Imig \& K. Sakai (Eds.), Can do statements in language education and beyond - Applications of the CEFR (pp.1934). Tokyo: Asahi Press.

National Education Examinations Authority (NEEA). (2018). China's standards of English language ability. Ministry of Education of the People's Republic of China.

Negishi, M. \& Tono, Y. (2014). An update on CEFR-J project and its impact on English language education in Japan. Paris ALTE.

Negishi, M. Takada \& Tono, Y. (2013). A progress report on the development of the CEFR-J In Galaczi, E.D. \& Weir. C.J. (Eds) Exploring language frameworks: Proceedings of the ALTE Kraków Conference, July 2011, Studies in Language Testing, 36, 135-163. Cambridge: UCLES/Cambridge University Press,

Nguyen, H. N. (2015). Vietnam's national foreign language 2020 project: challenges, opportunities and solutions. In S. Sharbawi \& T. W. Bigalke (Eds.), English for ASEAN integration: policies and practices in the region (pp. 62-64). Brunei: Universiti Brunei Darussalam. Retrieved from http://bruneiusprogramme.org/2013- forumpublication

Nguyen, H. T. ,Wilkinshaw, I. , \& H. H. Pham ( 2017) EMI Programs in a Vietnamese University: Language, Pedagogy and Policy Issues. In FentonSmith, B., Humphreys, P., Wilkinshaw, I, (eds.), English medium instruction in higher education in Asia-Pacific: Multilingual education (Vol. 21, pp. 37-52). Chem: Springer.

Nguyen, V.H. \& Hamid. M.O. (2015). Educational Policy borrowing in a Globalized World: A Case Study of Common European Framework of reference for Languages in a Vietnamese University. Journal of English Teaching, Practice and Critique, 14(1), 60-74. doi: 10.1108/ETPC-022015-0014

North, B. (2000). The development of a common framework scale of language proficiency. New York: Peter Lang.

North, B. (2004, April 15). Europe's framework promotes language discussion, not directives. The Guardian. Retrieved from https://www.theguardian.com/education/2004/apr/ $15 /$ tefl6

North, B. (2007). The CEFR illustrative scales. The Modern Language Journal, 94(4), 656-659 doi: 10.1111/j.1540-4781.2007.00627_3.x

North, B. (2008). EQUALS Bank of Descriptors - as Levels. EAQUALS/ALTE Portfolio Descriptor Revision Project. The European Association of Quality Language Services. [Online URL] https://rm.coe.int/1680492ff1

North, B., Oretega, A., \& Sheehan, S. (2010). A Core Inventory for General English. British Council: EAQUALS. Retrieved from https://www.teachingenglish.org.uk/sites/teacheng/ files/pub-british-council-eaquals-coreinventoryv2.pdf

Papageorgiou, S. (2010). Investigating the decisionmaking process of standard setting participants. Language Testing, 27(2), 261-282. doi: $10.1177 / 0265532209349472$

Pitsuwan, S. (2014). English as a powerful instrument of community building in East Asia. Teachers of English to speakers of other languages (TESOL) International Convention 2014, Portland, Oregon, USA.

Pollack, J. (2018 April 7). Dr. Teerakiat Jareonsettasin, The Prime Minister of Education in Thailand. [Online URL] https://expatlifeinthailand.com/education/drteerakiat-jareonsettasin-the-minister-of-educationin-thailand/

Poszytek, P. (2012). Policy perspectives from Poland. In M. Byram \& L. Parmenter (Eds.) The common European framework of reference: The globalization of language education policy (pp. 97-103). Bristol Multilingual Matters.

Renandya, W. A., Hamied, F.A., \& Nurkamto. J. (2018). English Proficiency in Indonesia: Issues and Prospects. The Journal of AsiaTEFL 15(3), 618-629. doi: 10.18823/asiatefl.2018.15.3.4.618

Salamoura, A. \& Saville, N. (2010). Exemplifying the CEFR: criterial features of written learner English from the English Profile Programme. In I Bartning and M. Marten (Eds) Communicative Proficiency and Linguistic Development: Intersection between SLA and Language Testing Research: Eurosla Monograph Series 1 (pp 102-132). European Second Language Association. Retrieved from http://eurosla.org/monographs/EM01/EM01home. html

Saussure, F. de,. (1914/74). Course in General Linguistics. London Fontana. (English Translation).

Seidlhofer, B. (2007). Common Property: English as a lingua franca in Europe. In J. Cummins, C. Davison (Eds) International Handbook of Language Teaching (pp. 137-150). London: Springer.

Tono, Y. \& Negishi, M. (2012, September). The CEFRJ: Adapting the CEFR for English language 
teaching in Japan. Framework \& Language

Portfolio (FLP) SIG Newsletter, 8, 5-12.

Trim, J.L. M (1980) Developing a Unit/Credit scheme of adult language learning. Oxford: Pergamon

UNDP (2015). The millennium development report.

United Nations Development Programme.

Retrieved from

https://www.th.undp.org/content/dam/thailand/doc s/UNDP_TH\%20MDG2015English.pdf

Van Ek, J.A. \& Trim J.L.M. (1990). Threshold 1990.

Cambridge: Cambridge University Press.
Viet, H. P. (2015). The CEFR in Vietnam from adoption to adaption. 41st Annual International Conference on Language. November 20, 2015. Shizuoka Prefecture, Japan.

West, R. (2015). Keeping it in the family. English Language Teaching Professional, 97, 60-62. 